\title{
Motivation as a Tool for Effective Staff Productivity in the Public Sector: A Case Study of Raw Materials Research and Development Council of Nigeria
}

\author{
Anwar Ali Shah G. Syed ${ }^{1}$, Lawal Muhammad Anka², Muhammad Bachal Jamali ${ }^{3}$ \& F. M. Shaikh ${ }^{4}$ \\ ${ }^{1}$ Daddu-Campus, University of Sindh-Jamshoro, Pakistan \\ ${ }^{2}$ Zamfara Agricultural and Rural Development Authority, Samaru Gusau, Zamfara State, Nigeria \\ ${ }^{3}$ Department of Commerce, SALU, Khairpur Mirs, Pakistan \\ ${ }^{4}$ Z A Bhutto Agricultural College, Dokri, Sindh, Pakistan
}

Correspondence: F. M. Shaikh, Z A Bhutto Agricultural College, Dokri, Sindh, Pakistan. E-mail: faizanmy2000@hotmail.com; faizmuhammed_2000@yahoo.com

Received: March 14, 2012 Accepted: May 27, 2012 Online Published: August 17, 2012

doi:10.5539/ass.v8n11p85 URL: http://dx.doi.org/10.5539/ass.v8n11p85

\begin{abstract}
The study examined the views of junior and senior staff of Raw Materials Research and Development Council (RMRDC), Nigeria concerning motivation as a tool for enhancing productivity. To achieve this, the study examined how employees could be motivated so as to achieve desired objectives. The research is based on information obtained from available records, personal observation and interview conducted. The major conclusions drawn from this research were survey results revealed that $26(39.3 \%)$ of the respondents are satisfied with their jobs, while majority of them $40(50.6 \%)$ are not satisfied with their jobs. Respondents opinion regarding mode of promotion in the organisation revealed that $44(66.6 \%)$ are satisfied while $20(30.3 \%)$ are not satisfied with the entire process. Perception of respondents in relation to what actually motivate them to do their best to enhance productivity the results conclude that $20(30.3 \%)$ prefer job security, $16(24.2 \%)$ accepted in service training while $12(18.1 \%)$ and 18 (27.2) prefer improved salary and promotion as factors that can motivate employees to perform their duties. Finally, the above results conclude that the Management of RMRDC did not motivate its staff to achieve productivity, efficiency and effectiveness. Therefore Null Hypotheses $\mathrm{H}_{\mathrm{o}}$ is accepted and Alternate Hypotheses $\mathrm{H}_{\mathrm{A}}$ is rejected. It is recommended that appropriate managerial actions must therefore be taken by the organisation that is motivation of the workforce.
\end{abstract}

Keywords: motivation, tool, staff productivity

\section{Introduction}

The word motivation is derived from a Latin word Move in its meaning move in its simplest term. The term may be defined as the state or condition of being induced to do something. The need to increase productivity and efficiency in the work place of any organisation has led to increasing academic interest in the area of motivation over the years. Writers have been keenly interested in knowing what factors are responsible for stimulating the ability to work. Thus motivation has become an issue of concern for both scholars and practitioners of public administration (Anka, 1992).

Every organisation either public or private is goal oriented and all efforts are geared towards the successful attainment of those goals and objectives. Therefore, for any organisation to record any degree of meaningful success in the pursuit of its goals and aspirations, it must have the ability to create values (motivation) enough to compensate for the burden imposed upon employees. Such value or motivators can come in the form of good training policies, facilities or incentives such as fringe benefits, promotions, status symbol etc so as to satisfy the needs of the employees for enhanced performance (Adi, 2000).

It was argued and proved that unless individual employees are motivated to make efficient use of the potentials found in them during the employment process, they may not achieve the level of performance that is desired from them (Rothberg, 2005). 
For an employee to be motivated, he or she perceived that their want are being met. Thus, the satisfaction of the employee represents an indispensable dimension of the motivational process. A satisfied individual would certainly contribute positively to the realisation of organisational goals and objectives, while a dissatisfied employee may not only contribute but can even act in such a way that the realisation of such goals and objectives could be completely destroyed. This underlines the importance of employees' satisfaction to the organisation (Anka, 1988).

It is generally believed that incentives such as good pay, good condition of service, provision of decent accommodation, opportunity for staff to undergo in service training etc motivates employees in order to increase their productive capacity. In view of the above, incentives are regarded as the major factor which motivates employees to exhibit better performance (Oshagbemi and Ocholi, 2006).

Finally, the test for management of either private or public organisation therefore, is to determine the valued needs and motivators that will make an employee react accordingly to the organisational desires to increase productivity.

\subsection{Problem Statement}

The primary mandate of Raw Materials Research and Development Council (RMRDC) is to draw up policy guidelines and action programmes on raw materials acquisition, exploitation and development. However, the question now is have the mandate been carried out as expected? Are the services of the Council being efficiently and effectively delivered to the people? The general perception of the people was that Raw Materials Research and Development Council (RMRDC) has not been performing to expectation. Even where the services are of huge financial commitments met by the government in ways of remuneration and other fringe benefits, the services has been dormant or in most cases embarrassingly inefficient and ineffective. Many factors contribute to this unfortunate situation but the most outstanding one could be the issue of laxity on part of the employees mainly due to deep dissatisfaction with their work.

\subsection{Objective of the Study}

The objectives of the paper were to:

- To identify what motivate employees in the Raw Materials Research and Development Council (RMRDC).

- $\quad$ To examine the relationship between motivation and productivity.

- Investigate if adequate motivational facilities are provided by Raw Materials Research and Development Council (RMRDC) for its employees.

To recommend ways through which Raw Materials Research and Development Council (RMRDC) could motivate its staff.

\subsection{Hypothesis}

- $\quad \mathrm{H}_{\mathrm{o}}$ If Inefficiency and Unproductivity are on the ineffectiveness are on increase in Raw Materials Research and Development Council (RMRDC) then motivation did not achieve the desired result

- $\quad \mathrm{H}_{\mathrm{A}}$ If Efficiency and Productivity are achieved in Raw Materials Research and Development Council (RMRDC), then motivation has achieved the desired result.

\subsection{Scope and Limitation of the Study}

To fully examine motivation Raw Materials Research and Development Council (RMRDC) was used as a unit of analysis. There was also the problem of cooperation on part of staff to give detail opinion about staff motivation in the organisation.

\section{Review of Literature}

Shah and Pathan (2009) explores the changes in productivity with major supposition of quantifying the relationships in terms of changes in the production caused by motivation among workers in maintaining secrecy, and security of confidential data. The study concludes that changes in productivity as gains in profitability are significantly related to motiivation levels at all three tiers of organisation structures.

Anka L. M. (2006) examines the essential skills needed by managers to work efficiently and effectively in an organisation. At lower level, the major need is for technical and human skills and at higher level manager's effectiveness depends largely on human and conceptual skills. At top level conceptual skills becomes the most important for successful administration. The three skills above play an important role in enhancing efficiency 
and effectiveness in an organisation.

According to Campbell and Pitchard (1976), motivation has to do with a set of independent, dependent viable relationship that explains the direction of skill and understanding of the task and constraints operating in the environment.

Glueck (1980) defines motivation as the process or factors (motives) that influence people to act. He went further to state that psychologists view motivation as the process, and channelling behaviour into a specific course.

Ajibola (1976) defined motivation as a process of stimulating people to achieve organisational task as well as a process of stimulating oneself to action to gratify a felt need. Maduaburn (1988) state that motivation is an inner state that energises, activates,moves, directs or channel behaviours toward achieving a desired goal. To him motivation is a general class that drives desires, needs wishes and related factors which mobilise behaviour towards their realisation or satisfaction.

Steers and Porter (1979) presents a model of the process of motivation as follows:

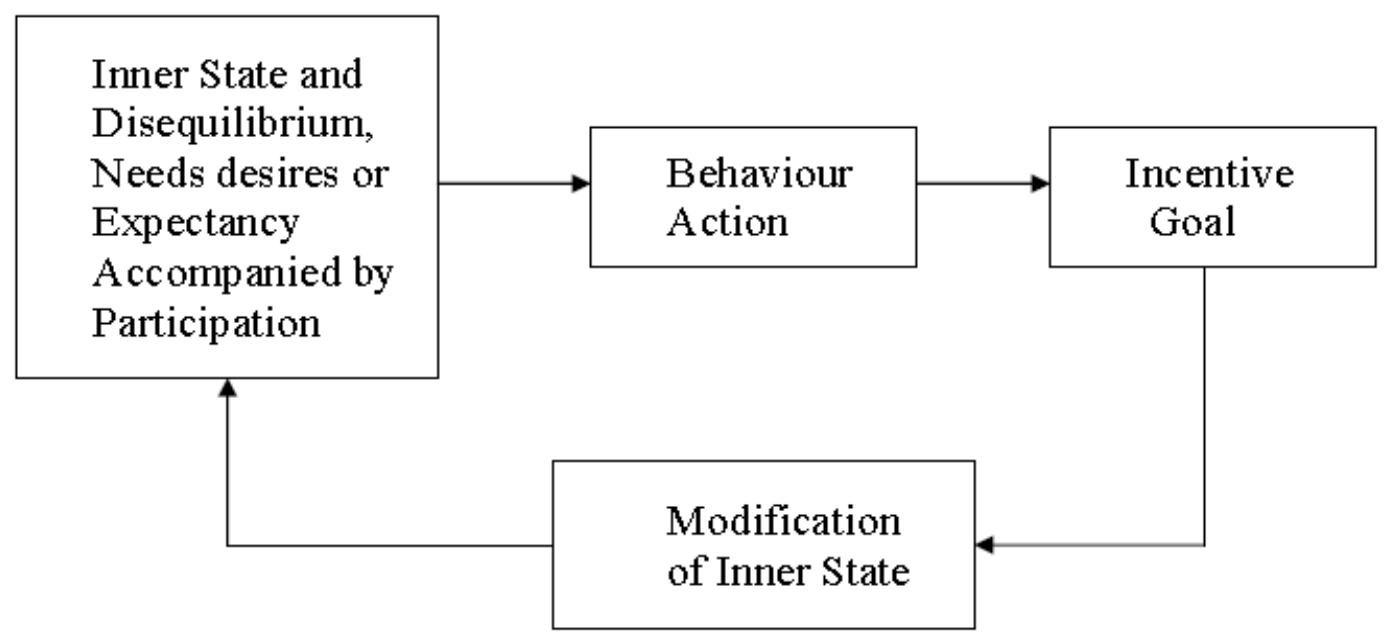

Figure 1. Model of process of motivation

Source: Steers and Porter 1976, Page 103

This model implies that individuals have desired needs within them that leads to the development of behaviour aimed at meeting their goals or needs. A feed back is then necessary in order to assess who either the behaviour is producing the desired goals or if there is the need for modification is something that originates from the inner state of an individual.

According to Decenzo and Robbins (2007) motivation is a multifacated process with individual managerial and organisational implication. Motivation is not what the employer exhibit but a collection of environmental issues surrounding the job.

Zubair (2005) identifies factors that motivate employees in Pakistani organisations. Twenty eight key motivational factors were identified, about 1,230 respondents were asked to rank their top ten motivators in their respective organisations. The results of the study revealed that top five motivators in Pakistani organisations were image, job security, compensation, good relationship and teamwork.

\section{Methodology}

Methodology is defined as a philosophy of research process which includes the assumptions and values that serve as rationale for researching conclusions.

The method of research adopted for this study is the use of available data and survey method.

(a) Instrument-Relevant data for the study was collected through the use of face to face structured interview. The questions for the interview were written before hand and asked for this same order. Another instrument used for this study is available data. Records concerning quality of service test were examined, other documents like annual report, of Raw Materials Research and Development Council (RMRDC) in brief prospectus for research and development were examined. 
(b) Population-The total population of Raw Materials Research and Development Council (RMRDC) Abuja Head Office at the time of research was 840. This includes both junior. senior and management staff.

(c) Sample-A connivance sample of 66 out of total 840 were interviewed.

(d) Method of Data Analysis-Simple percentage and descriptive methods of data analyses was used.

\section{Theoretical Frame Work}

The main reason of the failure of the civil is because integration between organisational goal and individual goal is not balanced. The goals of individual such as pleasure search for security to overwhelm the entire system there by resulting into inefficiency.

Mc Gregor (1960) proposes a set of assumptions on human motivation; he calls theory $Y$ that is the integration of individual goals with that of the organisation. Agyris (1971) believes that people are inclined by nature to expand psychology energy towards some purpose and that their personal needs tend to have a priority over organisational needs. People use their energy to subvert the end sought by organisation if management fails to recognise their needs.

Majority of workers in Raw Materials Research and Development Council (RMRDC) cannot meet the basic needs of life which Mashlow classified as elemental need that is needed to be met before one can think of anything else satisfying those needs can energise and direct the behaviours of workers but since this is not done, the integration of individual goal and organisational goal have become imbalanced, resulting to inefficiency and ineffectiveness.

\subsection{Organisational Structure of RMRDC}

The hierarical arrangement of the organisation is headed by Governing Council which reports to the Federal Ministry of Science and Technology, the supervisory ministry. In the absence of Governing Council, the Honourable Minister of science and Technology takes charge of the affairs of the Council.

The Executive Board of Raw Materials Research and Development Council (RMRDC) is made up of the Director General as the Chief Executive Officer (CEO) and six Directors in the organisation, these are Finance and Administration, Zonal Offices Coordination, Technology Development, Research Coordination, Investment Promotion, and Information and Computer Services.

The organisation maintains 36 Liaison Offices located in each of the State Capital. The Liaison Officer is the Officer in charge of all activities of Raw Materials Research and Development Council (RMRDC) at State level. The following Officers assist the Liaison Officer in fulfilling the Council's mandate: - Scientific Officer, Accountant and Administrative Officer.

\subsection{Services Provided by RMRDC to the Public}

Raw Materials Research and Development Council (RMRDC) provide the following services to the Nigeria public:

(a) Public policy advisory support.

(b) Serving as Nigeria's focal point for International collaboration on raw materials development.

(c) Promoting Industrial raw materials research innovation and utilisation through merit awards.

(d) Raw materials information

(e) Working for resource utilisation in all the States of the Federation.

(f) Promoting the development of indigenous technology.

(g) Sponsoring research and development activities for raw materials utilisation and new products.

(h) Upgrading of research laboratories and promoting science and technology in Nigeria.

(i) Promoting new resource based investment through joint venture projects and technical support service

(j) Supporting agro-industrial raw materials (RMRDC, 2007). 


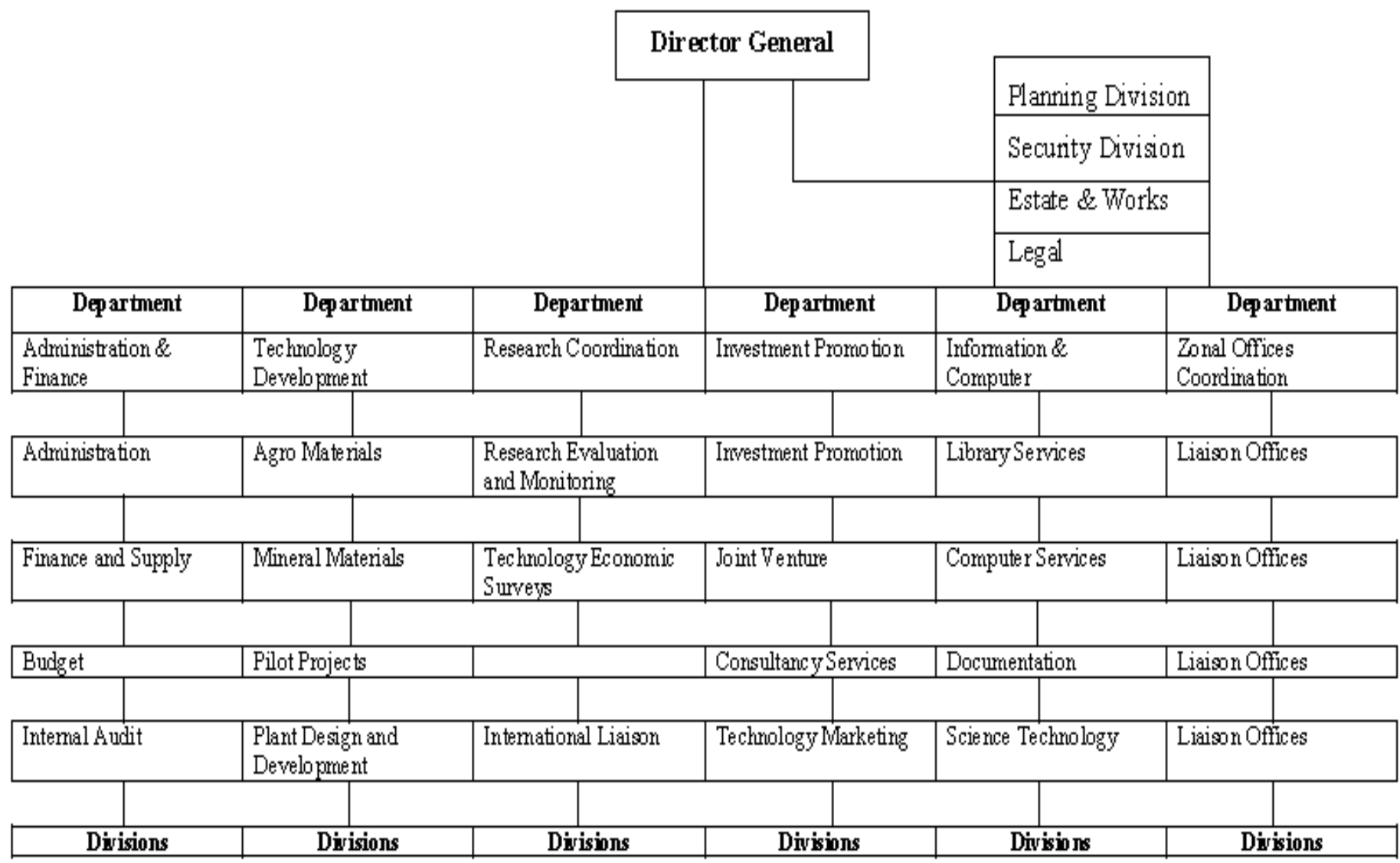

Figure 2. Organisational structure of raw materials research and development council (RMRDC)

Source: Brief on Vision, Mission, Activities and Achievements of RMRDC. Abuja, Nigeria, 2009.

\section{Results and Discussion}

This section focuses on analysis and presentation of primary data collected based on motivation as a tool for enhancing productivity in the Raw Materials Research and Development Council (RMRDC) Abuja, Nigeria.

Respondents were randomly selected from various categories of staff in the organisation during the process of data collection. A total of 80 questionnaires were distributed among the staff of Raw Materials Research and Development Council (RMRDC) of this number, 66 were filled and returned.

Data collected was analysed by use of tables and simple percentages to summarise the responses of respondents.

Table 1. Age of respondents

\begin{tabular}{ccc}
\hline Age & Number & Percentage \\
\hline $20-30$ Years & 16 & $24.2 \%$ \\
$31-40$ Years & 24 & $36.3 \%$ \\
$41-50$ Years & 22 & $33.3 \%$ \\
$51-60$ Years & 4 & $6 \%$ \\
Total & 66 & $100 \%$ \\
\hline
\end{tabular}

Source: Field Work, 2011

Table 1 shows that $16(24 \%)$ of the respondents fall between the ages of $20-30$ years, $24(36 \%)$ of the respondents fall between the ages of $31-40 y e a r s, 22(33 \%)$ of the respondents fall between the age of $41-$ $50 y e a r s$ of age, while $4(6 \%)$ of the respondents fall between the ages of $51-60 y e a r s$ of age. This indicates that the Council has a substantial number of staff between the $31-40$ years. 
Table 2. Gender distribution

\begin{tabular}{ccc}
\hline Gender & Number & Percentage \\
\hline Male & 66 & $100 \%$ \\
Female & 0 & $0 \%$ \\
Total & 50 & $100 \%$ \\
\hline
\end{tabular}

Source: Field Work, 2011

Data presented in Table 2 shows that all the respondents $66(100 \%)$ are males as there was no female respondents in the sample. This does not mean that there were no female workers in the Raw Materials Research and Development Council (RMRDC). Although majority of the staff are males.

Table 3. Marital status of respondents

\begin{tabular}{ccc}
\hline Status & Number & Percentage \\
\hline Married & 46 & $69.6 \%$ \\
Single & 10 & $15.1 \%$ \\
Divorced & 2 & $3.0 \%$ \\
Widowed & 8 & $12.0 \%$ \\
Total & 66 & $100 \%$ \\
\hline
\end{tabular}

Source: Field Work, 2011

Perceptions of respondents regarding marital status presented in Table 3 shows that $46(69.6 \%)$ are married 10 $(15 \%)$ are single while $8(12 \%)$ and $2(3 \%)$ are divorced and widowed respectively. This means that majority of the staff are married and have families.

Table 4. Duration of stay with RMRDC

\begin{tabular}{ccc}
\hline Years & Number & Percentage \\
\hline $1-5$ Years & 22 & $33.3 \%$ \\
$6-10$ Years & 26 & $39.3 \%$ \\
$11-15$ Years & 10 & $15.1 \%$ \\
$16-20$ Years & 6 & $9.0 \%$ \\
20 and above & 2 & $3.0 \%$ \\
Total & 66 & $100 \%$ \\
\hline
\end{tabular}

Source: Field Work, 2011

Survey results in Table 4 showed that 22 (33.3\%) of the respondents have been serving between $1-5 y e a r s$ in the organisation. Another 26 (39.3\%) have been in continuous service between 6 - 10years, while 10 (15.1\%) have been serving between $11-15 y$ ears, 6(9\%) and 20 and above were serving between 16 - 20years and 20 and above respectively. This indicates that majority of the respondents have been in the service of Raw Materials Research and Development Council (RMRDC) for over 10years.

Table 5. Satisfaction with the job

\begin{tabular}{ccc}
\hline Response & Number & Percentage \\
\hline Yes & 26 & $39.3 \%$ \\
No & 40 & $60.6 \%$ \\
Total & 66 & $100 \%$ \\
\hline
\end{tabular}

Source: Field Work, 2011

The above Table indicates that $26(39.3 \%)$ of the respondents are satisfied with their jobs while majority of them $40(60.6 \%)$ are not satisfied with their jobs due to one reasons or the other. 
Table 6. If you are offered employment elsewhere will you accept it?

\begin{tabular}{ccc}
\hline Response & Number & Percentage \\
\hline Yes & 48 & $72.7 \%$ \\
No & 18 & $27.2 \%$ \\
Total & 66 & $100 \%$
\end{tabular}

Source: Field Work, 2011

Data presented in Table 6 reveals that majority of the respondents $48(72.7 \%$ agreed that they will leave the organisation to take up appointment if given the opportunity. Only 18 (27.2\%) of the respondents showed their willingness to remain in the organisation even if offered opportunity elsewhere.

Table 7. Does the style of leadership motivates you?

\begin{tabular}{ccc}
\hline Response & Number & Percentage \\
\hline Yes & 10 & $15.1 \%$ \\
No & 50 & $76.0 \%$ \\
No Response & 6 & $9.0 \%$ \\
Total & 66 & $100 \%$ \\
\hline
\end{tabular}

Source: Field Work, 2011

Perception of respondents regarding style of leadership and motivation is presented in Table 7. The results revealed that $10(15 \%)$ respondents are motivated by the style of leadership in the organisation, $50(76 \%)$ said they are not motivated by the style of leadership in the organisation. While the remaining $6(9 \%)$ did not respond to the question.

Table 8. Have you been offered in-service training?

\begin{tabular}{ccc}
\hline Response & Number & Percentage \\
\hline Yes & 52 & $78.7 \%$ \\
No & 14 & $21.2 \%$ \\
Total & 66 & $100 \%$
\end{tabular}

Source: Field Work, 2011

According to information presented in Table 8, 52(78.7\%) of the respondents have benefited from in-service training while $14(21.2 \%)$ did not.

Table 9. Can lack of training affects your productivity?

\begin{tabular}{ccc}
\hline Response & Number & Percentage \\
\hline Yes & 62 & $93.9 \%$ \\
No & 4 & $6.0 \%$ \\
Total & 66 & $100 \%$ \\
\hline
\end{tabular}

Source: Field Work, 2011

Table 9 shows that majority of the respondents 62 (93.9\%) agreed that lack of training affects productivity, while $4(6 \%)$ of the respondents believe that lack of training would not affect productivity and performance.

Table 10. Are you regularly promoted?

\begin{tabular}{ccc}
\hline Response & Number & Percentage \\
\hline Yes & 44 & $66.6 \%$ \\
No & 20 & $30.3 \%$ \\
No Response & 2 & $3.0 \%$ \\
Total & 66 & $100 \%$ \\
\hline
\end{tabular}

Source: Field Work, 2011

The opinion regarding mode of promotion in the organisation are shown in Table 10 and the results revealed that 
$44(66.6 \%)$ of the respondents are satisfied while $20(30.3 \%$ of the respondents are not satisfied. It is clear that majority of the respondents are satisfied with the mode of promotion.

Table 11. How is your working relationship?

\begin{tabular}{ccc}
\hline Responses & Number & Percentage \\
\hline Good & 15 & $23 \%$ \\
Cordial & 27 & $41 \%$ \\
Satisfactory & 20 & $30 \%$ \\
Not Satisfactory & 2 & $3 \%$ \\
Poor & 2 & $3 \%$ \\
Total & 66 & $100 \%$ \\
\hline
\end{tabular}

Source: Field Work, 2011

The data pertaining to working relationship are reported in Table 11. Survey results revealed that $15(23 \%)$ of the respondents feel that the relationship between employees in the organisation was good, 27 (41\%) maintained cordial relationship, $20(30 \%)$ said it is satisfactory, $2(3 \%)$ reported not satisfactory. While $2(3 \%)$ said it is poor. The above findings concludes that there is a good rapport among the employees of the organisation.

Table 12. How do you rate job security?

\begin{tabular}{ccc}
\hline Responses & Number & Percentage \\
\hline Low & 27 & $41 \%$ \\
Satisfactory & 22 & $33 \%$ \\
High Secure & 8 & $12 \%$ \\
No Response & 9 & $14 \%$ \\
Total & 66 & $100 \%$ \\
\hline
\end{tabular}

Source: Field Work, 2011

Survey results in Table 12 showed that 27 (41\%) of the respondents are of the view that the level of security is low, $22(33 \%)$ rate it as satisfactory, $8(12 \%)$ rate it as high secure, while $9(14 \%)$ did not respond to the question. The reason for fear of job security could probably be due to mass retrenchment from time to time. It is important to note that when workers have a feeling of job insecurity, they tend to be disorganised and live in perpetual fear of loosing their job unexpectedly. This result in low level of productivity as employees will not concentrate and put in their best in the work place due to uncertainty.

Table 13. What do you think can motivate you to perform your duties?

\begin{tabular}{ccc}
\hline Motivators & Number & Percentage \\
\hline Job Security & 20 & $30.3 \%$ \\
In-service Training & 16 & $24.2 \%$ \\
Improved Salary & 12 & $18.1 \%$ \\
Promotion & 18 & $27.2 \%$ \\
Total & 66 & $100 \%$ \\
\hline
\end{tabular}

Source: Field Work, 2011

Perception of respondents in relation to what actually motivate respondents to put in their best to enhance productivity, the results in Table 13 revealed that $20(3.3 \%)$ prefer job security, $16(24.2 \%)$ accepted in-service training while $12(18.1 \%)$ and $18(27.2 \%)$ prefer improved salary and promotion as factors that motivate employees to perform their duties. The above findings proved that there are different things that could motivate employees making motivation a complex issue. Management of all organisations have to identify what could motivate their employees from time to time. 
Table 14. Do you really need the following incentives?

\begin{tabular}{ccc}
\hline Incentives & Number & Percentage \\
\hline Accommodation & 34 & $52 \%$ \\
Medical facilities & 22 & $33 \%$ \\
Transport allowance & 5 & $7.5 \%$ \\
Overtime allowance & 5 & $7.5 \%$ \\
Total & 66 & $100 \%$ \\
\hline
\end{tabular}

Source: Field Work, 2011

The opinion regarding incentives that motivates performance in an organisation are shown in Table 14 and the results revealed that $34(52 \%)$ of the respondents need residential accommodation, while $22(33 \%)$ prefer medical facilities. Equally, on the same proportion $5(7.5 \%)$ and $5(7.5 \%)$ need transport and overtime allowance respectively. It is clear from the foregoing results that majority of respondents in the Raw Materials Research and Development Council (RMRDC) gave accommodation and medical facilities more importance compared to transport and overtime allowance.

\subsection{Problems and Observations Noted during this Research}

- $\quad$ This research revealed that the Raw Materials Research and Development Council (RMRDC) has been characterised by poor delivery of its functions which is manifested in its ineffectiveness and inefficiency. This has led to low productivity.

One major problem discovered is that workers are not satisfied with their jobs and there is a high rate of job insecurity in the service.

- Majority of the staff are willing to leave the organisation if they found the opportunity of getting another job.

It was discovered that the leadership style in the organisation does not motivate staff and other motivational factors like promotion, accommodation, transport and overtime allowance are not available only medical facilities are available through the National Health Insurance Scheme.

- The abysmal performance of Raw Materials Research and Development Council (RMRDC) could be as a result of lack of motivation from the government.

\section{Summary, Conclusions and Recommendations}

\subsection{Summary}

The study examined the views of junior and senior staff of Raw Materials Research and Development Council (RMRDC) concerning motivation as a tool for enhancing productivity in the Raw Materials Research and Development Council (RMRDC), Head Office Abuja, Nigeria. To achieve this, the study examined how employees could be motivated so as to achieve the desired objectives productivity, efficiency and effectiveness.

This research is based on information obtained from available records, personal observation and interview conducted. In the process, we discovered that the continued survival of any organisation depends on its ability to achieve its set goal and objectives. Appropriate managerial actions must therefore be taken by the organisation that is motivation of the workforce.

\subsection{Conclusion}

The major conclusions drawn from this paper were:

- $\quad$ Survey results revealed that $26(39.3 \%)$ of the respondents are satisfied with their jobs while majority of them $40(60.6 \%)$ are not satisfied with their jobs.

- It was also discovered that majority of the respondents 48 (72.7\%) agreed that they will leave the organisation if given the opportunity, only $18(27.7 \%)$ of the respondents accepted to remain in the organisation if offered opportunity elsewhere.

Perception of respondents regarding in service training offered by the organisation showed that 52 (78.7\%) of the respondents have benefited from in-service training while $14(21.2 \%)$ did not.

- $\quad$ Respondents opinion regarding mode of promotion in the organisation revealed that $44(66.6 \%)$ of the respondents are satisfied while $20(30.3 \%)$ are not satisfied with the entire process. 
- Survey results on how you rate job security in the organisation showed that $27(41 \%)$ of the respondents are of the view that the level of security is low, $22(33 \%)$ rate it as satisfactory while $8(12 \%)$ rate it as highly secured.

Perception of respondents in relation to what actually motivate them to do their best to enhance productivity, the results conclude that $20(30.3 \%)$ prefer job security, $16(24.2 \%)$ accepted in-service training, while $12(18.1 \%)$ and $18(27.2 \%)$ prefer improved salary and promotion as factors that can motivate employees to perform their duties.

The opinion regarding incentives that motivates performance in the organisation revealed that 34 $(52 \%)$ of the respondents need residential accommodation, while $22(33 \%)$ prefer medical facilities. Equally, on the same proportion $5(7.5 \%)$ and $5(7.5 \%)$ need transport and overtime allowance respectively.

The data pertaining to working relationships have shown that $15(23 \%)$ of the respondents feel that the relationship between employees in the organisation was good, 27 (41\%) maintained cordial relationship, $20(30 \%)$ said it is satisfactory, Equally on the same proportion $2(3 \%)$ reported not satisfactory, while $2(3 \%)$ said it is poor.

Finally, the above results conclude that the Management of Raw Materials Research and Development Council (RMRDC) did not properly motivates its staff to achieve efficiency and effectiveness. Therefore Null Hypothesis $\mathrm{H}_{\mathrm{o}}$ is accepted and Alternate Hypothesis $\mathrm{H}_{\mathrm{A}}$ is rejected.

\subsection{Recommendations}

On the basis of the above conclusions the following recommendations are made that will go a long way in motivating employees to put in their best in the discharge of the duties for enhanced productivity:

- $\quad$ Raw Materials Research and Development Council (RMRDC) should encourage employees on a regular basis. Training is a great motivator and should be given top priority.

Salary is also a great motivator, should be paid on a regular basis. In view of inflationary trends, salaries should be reviewed.

Regular promotion is recommended as it also serves as incentive for motivation to enhance productivity in the public sectors. Promotion gives individuals monetary benefits and recognition of individual performance and inner satisfaction leading to improved job performance, efficiency and effectiveness.

- $\quad$ Raw Materials Research and Development Council (RMRDC) should put extra efforts in providing accommodation to its staff particularly intermediate and junior staff in the headquarters at Abuja find it very difficult to get reasonable accommodation. The management should look into the matter very seriously.

- $\quad$ Raw Materials Research and Development Council (RMRDC) has provided medical facilities for its staff through the National Health Insurance Scheme. This is a commendable effort.

In the preparation and submission of the budget, Raw Materials Research and Development Council (RMRDC) should make special provision for meeting staff welfare so that all allowances and other fringe benefits of staff are met appropriately without any delay.

Payment of special bonuses for employees who have outstandingly performed in a particular year should be introduced by Raw Materials Research and Development Council (RMRDC) where such bonuses are not possible, the organisation should give letters of commendation for excellent performance and other honorary awards should be given to deserving staff.

- Raw Materials Research and Development Council (RMRDC) should evolve a well specified schedule of duty so that each and every member of staff should clearly know when and where he is responsible. Schedule of duty is an indispensable tool for smooth execution of jobs without confusion, chaos, overworking of some and under utilisation of others

\section{References}

Adi D. Y. (2000). Motivation As a Means of Effective Staff Productivity in the Public Sector: A case study of Nigeria Immigration Service, Borno State of Nigeria. Unpublished MPA Thesis. School University of Maiduguri, Nigeria.

Ajibola E. (1976, October). How to Motivate the Nigerian Workers. Nigerian Journal of Management.

Anka L. M. Anka. (1988, March-April). Corporate Objectives and Self Development: The Specialists 
International. Journal of Institute of Management Specialist, 3(5).

Anka L. M. Anka. (1992). Management Objectives As An Effective Management Tool: Pakistan Management Review. Journal of Pakistan, Institute Management, Karachi, XXVII(IX).

Anka L. M. Anka. (2006, Fourth Quarter). Motivational Skills Acquisition for Managers. Pakistan Management Review, XLIII(4).

Campbell J. P., \& Pritchard R. D. (1976). Motivation Theory: Industrial and Organisational Psychology. Mc Graw Hill Book, New York.

Decenzo D. A., \& Robbins S. P. (2007). Fundamental of Human Resource Management (8th ed.).

Glueck W. F. (1980). Management the Dryden Press Hinsdale Illinois, USA.

Maduaburn C. D. (1988). Motivation of Nigerian Civil servants: A Historical Overview. Quarterly Journal of Administration, 22(1-2).

Oshagbemi T., \& Ocholi S. (2006, Third Quarter). Leadership Styles and Behaviour Profiles of Managers. Pakistan Management Review, XLIII(3), 75-88.

RMRDC. (2007). Prospectus for Research and Development Programme Guidelines for Submission of Research Proposals: Raw Materials Research and Development Council. Abuja, Nigeria.

RMRDC. (2009). Brief on Vision Mission Activities and Achievements of Raw Materials Research and Development Council. Abuja, Nigeria.

RMRDC. (2010). Annual Report of Progress and Achievements of Materials Research and Development Council. Abuja, Nigeria.

Rothberg G. (2005, Fourth Quarter). The Role of Idea in the Managers workplace: Theory and Practice. Pakistan management Review, XLII(4), 48-73.

Shah J. A., \& Pathan P. A. (2009, June). Examining Causal Linkages between Productivity and Motivation: Grassroots Biannual Research, Journal of Pakistan Study Centre, XXXTX.

Steers R. M., \& Porter L. W. (1979). Motivation and Work Behaviour. Mc Graw Hill Book Company, New York.

Zubair Z. R. (2005). What Motivates employees in Pakistani Organisation: An In-depth Study of Preferred Motivators. Pakistan Institute of management, Karachi, Pakistan. 